\title{
Comparison Study of Molecular Diagnostic Reagents for COVID-19 Pooling Test
}

\author{
Dong Hee Seo ${ }^{1 \oplus}$, Geun-ju Son ${ }^{\circledR}$, and Jeong-woo Kang ${ }^{2 \oplus}$ \\ ${ }^{1}$ LabGenomics Clinical Laboratories and 2Division of Molecular Genetics Examination, LabGenomics Co., Seongnam, Korea
}

\section{Corresponding author: \\ Dong Hee Seo \\ LabGenomics Clinical Laboratories, LabGenomics Co., B-6F, 700 \\ Daewangpangyo-ro, Bundang-gu, Seongnam 13488, Korea \\ Tel +82-31-628-0730 \\ E-mail seo2023@labgenomics.com}

Received: July 6, 2021

Revised: September 7, 2021

Accepted: September 8, 2021
In Korea, real-time reverse transcription-polymerase chain reaction (PCR) is performed on individual or pooled samples to diagnosis coronavirus disease 2019 (COVID-19). New developed LabGun COVID-19 ExoFast RT-PCR Kit (LabGenomics, Korea) was compared to PowerCheck SARS-CoV-2 Real-time PCR Kit (KogeneBiotech, Korea) for its properness about COVID-19 pooling test. LabGun kit showed $98.75 \%$ concordance for positive samples and 100\% concordance for negative samples tested by PowerCheck kit. Agarose gel electrophoresis study revealed similar PCR products band intensities for two testing kits. In conclusion, LabGun kit could be used for COVID-19 pooling test.

(Lab Med Qual Assur 2021;43:214-6)

This is an Open Access article distributed under the terms of the Creative Commons Attribution Non-Commercial License (http://creativecommons.org/licenses/ by-nc/4.0) which permits unrestricted non-commercial use, distribution, and reproduction in any medium, provided the original work is properly cited.
Key Words COVID-19, RT-PCR testing, Pooling test
코로나바이러스감염증-19(코로나19)는 코로나바이러스의 일종인 severe acute respiratory syndrome coronavirus 2 (SARS-CoV-2)에 의해 발병하는 신종 전염병으로, 이를 진 단하기 위해서 국내에서는 분자유전학적인 실시간 역전사 polymerase chain reaction (PCR) 검사가 주로 시행되고 있 다[1,2]. 국내에서는 코로나19 진단을 위해 개별 검체에 대한 검 사뿐만 아니라 몇 개의 검체를 하나로 혼합하여 검사하는 취합 검사(선제검사)도 시행되고 있다[3]. 본 검사실에서는 실시간 역 전사 PCR 검사법으로 코로나19 개별검사 및 취합검사를 시행 하고 있다. 코로나19 취합검사의 시행에는 질병관리청의 사전 승인이 필요하다. 본 검사실에서 취합검사에 사용하고 있는 기 존의 코젠바이오텍의 PowerCheck SARS-CoV-2 Real-time PCR Kit (KogeneBiotech, Seoul, Korea; 체외 제허 20-1000 호)와 새로이 개발된 LabGun COVID-19 ExoFast RT-PCR Kit (LabGenomics, Seongnam, Korea; 체외 제허 21-202호)의 서 로 다른 PCR 조건에 따른 증폭산물의 증폭량 차이 유무에 대하여
비교시험해 보았다.

PowerCheck SARS-CoV-2 Real-time PCR 시약(PowerCheck)을 사용한 취합검사에서 양성 및 미결정 결과를 보인 172 건과 음성 186건에 대하여 LabGun COVID-19 ExoFast RT-PCR 시약(LabGun)을 이용하여 병행검사를 진행하였다. 취합검사 는 5 개의 검체를 혼합하여 이루어졌다. 개별 상기도 검체에서 각 $100 \mu \mathrm{L}$ 를 취하여 총 $500 \mu \mathrm{L}$ 를 만든 후에, 여기서 $200 \mu \mathrm{L}$ 를 취하 여 Nx-48 Viral NA kit VN103 (Genolution, Seoul, Korea) 시약 을 이용하여, 제놀루션 회사의 Nextractor NX-48 (Genolution, Seoul, Korea) 추출장비를 사용하여 바이러스 핵산을 추출하였 다. PowerCheck과 LabGun 모두 1튜브로 바이러스 타깃 유전 자를 증폭하며, 추출한 핵산 $5 \mu \mathrm{L}$ 와 검사시약 $15 \mu \mathrm{L}$ 를 혼합하여 총 $20 \mu \mathrm{L}$ 로 CFX96 Real-time system (Bio-Rad, Hercules, CA, USA)을 이용하여 PCR 검사를 진행하였다. 실시간 PCR 반응시간 은 PowerCheck이 약 1시간 30분, LabGun은 약 40분이 소요되 었다. 
기존 취합검사의 PowerCheck cycle threshold $(\mathrm{Ct})$ 값(양성 기준치 $=38)$ 을 기준으로 강양성 27 건 $(\mathrm{Ct}<20)$, 중양성 103 건 $(\mathrm{Ct}$, 20-30), 약양성 31건(Ct, 30-36), 미결정 11 건(Ct>36)으로 그룹 을 분류하여 검사를 시행하였다. 강양성 검체 27 건과 중양성 검체 103 건 모두에서 LabGun도 검사 양성을 보였다. 약양성 31건 중 2건은 LabGun에서 음성을 보였는데, 음성 2건의 PowerCheck Ct값은 35.03/35.42, 35.16/33.96이었고 LabGun Ct값(양성 기 준치=30)은 각각 not available (NA)/NA, 31.00/29.19를 보였 다. PowerCheck 미결정 11 건 중 3건이 LabGun에서 양성 결 과를 보였다. 취합검사 음성 186 건은 LabGun 검사에서도 모 두 음성을 보였다. 각 양성 그룹별로 10 개의 샘플을 선정하여, $2.5 \%$ agarose gel 전기영동을 통해 PCR 증폭산물의 양을 비 교하였다. Table 1 에 약양성에서 선정한 10 개 검체의 $\mathrm{Ct}$ 값이 나 와 있다. LabGun의 Ct값은 22.88에서 29.78까지 분포하고 있 다. PowerCheck은 바이러스의 ORF1ab와 E 유전자를 그리고 LabGun은 RdRp와 N 유전자를 검출한다(Table 1). Fig. 1은 약 양성 그룹의 $\mathrm{PCR}$ 증폭산물 $5.0 \mu \mathrm{L}$ 의 10 개 검체의 전기영동 사 진으로 PowerCheck과 LabGun 두 시약 모두 뚜렷한 양성 밴드 를 보여주었다. LabGun 시약을 사용한 실시간 역전사 PCR에서 $\mathrm{N}$ 유전자 표적 산물과 RdRp 유전자 표적 산물, 그리고 IC 증폭산 물 밴드를 관찰할 수 있다(Fig. 1). 강양성 10 개 검체와 중양성 10 개 검체의 전기영동에서도 두 시약 모두 비슷한 강도의 $\mathrm{PCR}$ 증폭 산물 밴드를 보였다. 실시간 역전사 PCR취합검사에서 LabGun은 기존 PowerCheck과 비교했을 때 양성 검체는 $98.75 \%$ 의 일치율
을 보였고, 음성 검체에 대해서는 $100 \%$ 일치율을 보였다. 또한 두 시약의 양성 판정 Ct값이 차이는 있지만, PCR 증폭산물의 전기영 동 비교평가에서 비슷한 강도의 증폭 수준을 확인할 수 있었다. 양 성 검체 161 개 중 2 건 불일치와 음성 검체 186 개 모두 일치 결과

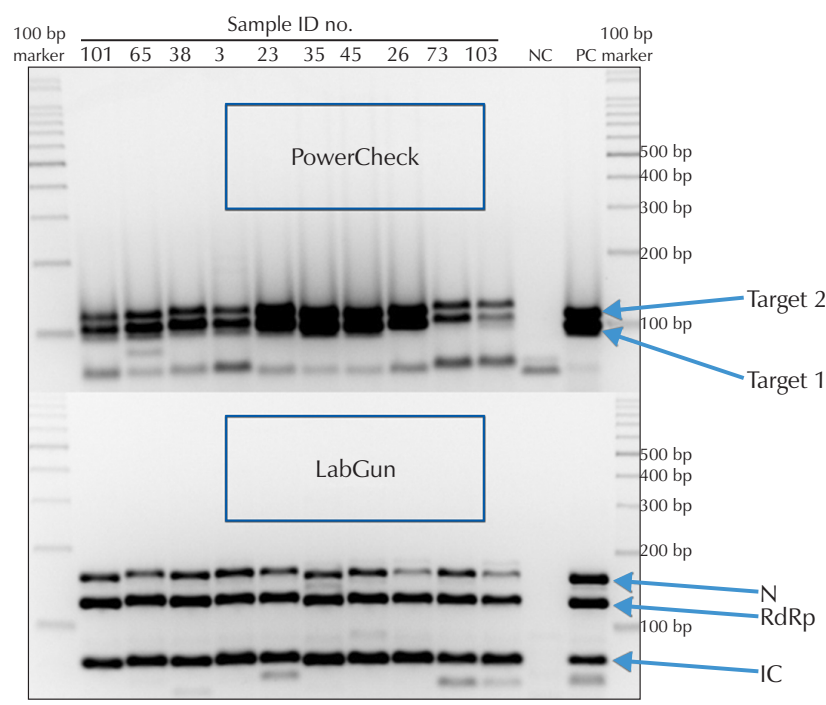

Fig. 1. 2.5\% agarose gel electrophoresis of 10 coronavirus disease 2019 positive samples. The instruments and reagents used were as follows: PowerCheck (KogeneBiotech, Seoul, Korea) and LabGun (LabGenomics, Seongnam, Korea). Abbreviations: IC, internal control; RdRp, RNA-dependent RNA polymerase; N gene, nucleocapsid gene.

Table 1. Cycle threshold values of coronavirus disease 2019 weakly positive 10 samples

\begin{tabular}{|c|c|c|c|c|c|c|c|}
\hline \multirow{2}{*}{ COVID-19 result } & \multirow{2}{*}{ Sample ID } & \multicolumn{3}{|c|}{ PowerCheck } & \multicolumn{3}{|c|}{ LabGun } \\
\hline & & ORF1ab & E gene & IC & $\mathrm{RdRp}$ & $\mathrm{N}$ gene & IC \\
\hline Positive & 101 & 30.36 & 32.43 & 30.77 & 22.88 & 25.02 & 19.76 \\
\hline Positive & 65 & 31.14 & 32.85 & 30.22 & 24.00 & 26.74 & 19.79 \\
\hline Positive & 38 & 31.24 & 32.56 & 32.06 & 23.35 & 25.64 & 21.12 \\
\hline Positive & 3 & 32.31 & 33.91 & 31.36 & 24.66 & 26.07 & 20.42 \\
\hline Positive & 23 & 34.31 & 35.66 & 31.87 & 25.25 & 27.48 & 21.55 \\
\hline Positive & 35 & 32.09 & 32.92 & 27.26 & 24.10 & 26.21 & 16.78 \\
\hline Positive & 45 & 32.06 & 34.28 & 27.03 & 24.22 & 26.39 & 16.77 \\
\hline Positive & 26 & 32.32 & 35.09 & 29.73 & 25.54 & 29.57 & 19.02 \\
\hline Positive & 73 & 31.37 & 34.15 & 35.09 & 25.25 & 27.04 & 24.02 \\
\hline Positive & 103 & 33.11 & 36.28 & 33.99 & 26.51 & 29.78 & 23.09 \\
\hline
\end{tabular}

The instruments and reagents used were as follows: PowerCheck (KogeneBiotech, Seoul, Korea) and LabGun (LabGenomics, Seongnam, Korea).

Abbreviations: ORF1ab, open reading frame 1ab; E gene, envelope gene; IC, internal control; RdRp, RNA-dependent RNA polymerase; N gene, nucleocapsid gene. 
를 가지고 kappa 통계량을 계산하면 0.988 로, kappa 값이 0.75 이상을 보여 매우 우수한 일치도를 보이는 것으로 나왔다[4]. 바이 러스 감염의 선별을 위한 취합검사는 헌혈혈액 선별검사에 사용된 적이 있었고[5], 대량의 검체를 신속하게 처리하기 위해서는 필요 한 검사로 여겨진다.

PowerCheck 시약은 국내에서 처음으로 2020년 4월에 긴급사 용승인을 받고, 2020년 11월에 식품의약처 정식 제품 허가를 득 한 체외진단의료기기로 현재 개별 및 취합검사에 사용되고 있다 [6]. LabGun은 2021년 3월에 식품의약처로부터 코로나19 진단 을 위한 체외진단의료기기로 정식 제품 허가를 받았다. 결론적으
로 이번 비교평가에서 LabGun은 기존의 PowerCheck과 유사한 $\mathrm{PCR}$ 시험성적을 보이고 PCR 반응시간이 짧아서, 코로나19 취합 검사에 사용할 수 있을 것으로 여겨진다.

\section{ORCID}

Dong Hee Seo https://orcid.org/0000-0003-0828-3773

Geun-ju Son https://orcid.org/0000-0001-5331-3113

Jeong-woo Kang https://orcid.org/0000-0003-2789-5345

\section{REFERENCES}

1. Kwon KS, Park JI, Park YJ, Jung DM, Ryu KW, Lee JH. Evidence of long-distance droplet transmission of SARS-CoV-2 by direct air flow in a restaurant in Korea. J Korean Med Sci 2020;35:e415.

2. Huh HJ, Hong KH, Kim TS, Song SH, Roh KH, Lee H, et al. Surveillance of coronavirus disease 2019 (COVID-19) testing in clinical laboratories in Korea. Ann Lab Med 2021;41:225-9.

3. Lee K. Laboratory diagnosis of COVID-19 in Korea. Ewha Med J 2021;44:1-10.

4. The Korean Society of Laboratory Medicine. Evaluation of test methods. In: The Korean Society of Laboratory Medicine, editor. Laboratory medicine. 6th ed. Seoul: Medicalplus, 2021;84-5.

5. Seo DH, Hwang BG, Park YS, Oh YC, Kim SI. Performance of HCV and HIV-1 nucleic acid amplification test(NAT) in Korean blood donors. Korean J Blood Transfus 2000;11:91-7.

6. Hur KH, Park K, Yang JJ, Kim MN, Sung H. Current status of proficiency testing programs and development of reference materials for severe acute respiratory syndrome coronavirus 2 molecular diagnostic tests. Lab Med Qual Assur 2020;42:194-9. 